\title{
PURIFICATION AND CHARACTERIZATION OF A NOVEL PROTEASE WITH FIBRINOLYTIC ACTIVITY FROM Mucor subtilissimus UCP 1262
}

\author{
A.E. SALES ${ }^{1}$, T. P. NASCIMENTO ${ }^{2}$,R. M. P. B COSTA ${ }^{1}$, C. S. PORTO, G. M. de \\ CAMPOS-TAKAKI ${ }^{3}$, A. L. F. PORTO ${ }^{1}$, T. S. PORTO ${ }^{4}$ \\ ${ }^{1}$ Universidade Federal Rural de Pernambuco, Departmento de Morfologia e Fisiologia Animal \\ ${ }^{2}$ Universidade Federal de Pernambuco, Centro de Ciências Biológicas \\ ${ }^{3}$ Universidade Católica de Pernambuco, Núcleo de Pesquisas em Ciências Ambientais \\ ${ }^{4}$ Universidade Federal Rural de Pernambuco, Unidade Acadêmica de Garanhuns \\ E-mail para contato: portots@yahoo.com.br
}

\begin{abstract}
A novel protease with fibrinolytic activity was purified from MucorsubtilissimusUCP 1262usinga two-step purification protocol.The enzyme was pre-purified using cetonic precipitation and adsorbed by ion exchange chromatography on DEAE-sephadex G50. System two-dimensional electrophoresis (2DE) coupled to SDS-PAGE showed a single protein band of $15.3 \mathrm{kDa}$ approximatelyand isoeletric focusing point of 3.9, exhibiting a nature as an acidic enzyme. The activity was suppressed by $\mathrm{Co}^{2+}$ and $\mathrm{HgCl}_{2}$, but slightly enhanced byCa ${ }^{2+}$. Additionally, the activity was slightly inhibited by EDTA, but significantlyinhibited by PMSF. It exhibited fibrinolytic activity, which is weaker than that of plasmin, but also had a higher affinity for the N-Succinyl-Ala-Ala-Pro-Phe p-nitroanilide (SAAPNA) and azocasein substrates, suggesting a chymotrypsin-like protease. These results demonstrated an economically viable protocol purification of a protease with fibrinolytic activity with high degree of purity that may represent a potential source of new therapeutic agents to treat thrombosis.
\end{abstract}

\section{INTRODUCTION}

Proteases constitute a large group of hydrolytic enzymes that cleave peptide bond of protein and degrade them into small peptides and amino acids. Among the different industrial enzymes, proteases make up $60 \%$ and they haveapplications mainly in food, detergents and leather processing industries (Anitha and Palanivelu, 2013).

The productionof microbial enzymes requires the investigation of the parameters that may affect enzyme yield, optimization of production and effective downstream processing techniques.Various natural-active enzymes purified from microbial sources have been extensively used in many fields. Among them, fibrinolytic enzymes have received attention fortheir potential medicinal use on thrombotic disease, which is becoming a leading cause of morbidity and mortality worldwide, yet most of current fibrinolytic agents available for clinic 
are barely satisfactory (Biet al, 2013).

The huge microbial diversity may potentially facilitate targeting novel fibrinolytic proteases with desired therapeutic attribute. In recent years, thrombolytic agents found in non-animal sources have received considerable attention because of their security(Kumar et al, 2013, Choi et al, 2013). Fibrin is formed from fibrinogen by the action of thrombin. Fibrin is lysed by plasmin, which is activated from plasminogen by tissue plasminogen activator. Hemostasis is a complex process that maintains the balance between fibrin formation and fibrinolysis. However, when fibrin hydrolysis is not complete because of a balance disorder, thrombosis, such as a myocardial infarction, can occur (Shirasaka et al., 2012).

The abnormal clot, called thrombus, within the vascular system obstructs the flow of blood and nutrient to vital tissues (Lu et al, 2010). Due to prevalence, these cardiovascular diseases are expected to impose an ever-increasing impact on our society emotionally, socially and financially (Kim et al., 2011).In this study, we therefore attempted to identify thrombolytic agent as a protease with fibrinolytic activity by fermentation from MucorsubtilissimusUCP 1262. The purification and characterization of this protease are also described.

\section{MATERIAL AND METHODS}

\subsection{Culture conditions for enzyme production}

The culture conditions of MucorsubtilissimusUCP 1262 for enzyme production were preliminarily optimized $\left(30^{\circ} \mathrm{C}, 120 \mathrm{rpm}\right)$. A 6-day culture of MucorsubtilissimusUCP 1262 in $7 \mathrm{~mL}$ Czapek Agar medium was used. The spores suspension at $10^{4}$ of concentration was inoculated into $100 \mathrm{~mL}$ medium liquid described by (Portoet al, 1996)withminor modificationsso thatwheatwas addedas a nitrogen source.

The medium consisted of wheat bran filtrate $\left(1 \%\right.$, w/v), $\mathrm{K}_{2} \mathrm{HPO}_{4}(0.435 \%$, w/v), and mineral solution $\left[\mathrm{FeSO}_{4} \cdot 7 \mathrm{H}_{2} \mathrm{O}(100 \mathrm{mg}), \mathrm{MnCl}_{2} \cdot 4 \mathrm{H}_{2} \mathrm{O}(100 \mathrm{mg})\right.$, and $\left.\mathrm{ZnSO}_{4} \cdot \mathrm{H}_{2} \mathrm{O}(100 \mathrm{mg})\right]$, $\mathrm{NH}_{4} \mathrm{Cl}(0.1 \%, \mathrm{w} / \mathrm{v}), \mathrm{MgSO}_{4} \cdot 7 \mathrm{H}_{2} \mathrm{O}\left(0.06 \%\right.$, w/v), and $\mathrm{CaCl}_{2}(1 \% \mathrm{w} / \mathrm{v})$ plus glucose $(1 \%, \mathrm{w} / \mathrm{v})$ dissolved in $100 \mathrm{mLof}$ distilled water. The culture medium was added in a shaking flask (250 $\mathrm{ml})$, which was incubated at $30^{\circ} \mathrm{C}$ on a shaker $(120 \mathrm{rpm})$ for 4 days. The culture broth was obtained by filtration and used for enzyme purification.

\subsection{Purification of protease with fibrinolytic activity}

The liquid metabolic obtained by fermentation $(300 \mathrm{~mL})$ was submitted to precipitation using $70 \%$ acetone. The resulting precipitate was collected through centrifugation at $15,000 \mathrm{xg}, 4^{\circ} \mathrm{C}$, for $30 \mathrm{~min}$. The pellet was dissolved in $100 \mathrm{mM}$ sodium acetate buffer, $\mathrm{pH} 7.5$, and the solution was dialyzed against the same buffer overnight at $4{ }^{\circ} \mathrm{C}$. The dialysate was concentrated by lyophilization and subsequently loaded into a DEAE-Sephadex chromatography process, using a column $(8.0 \times 1.0 \times 1.0 \mathrm{~cm})$ equilibrated with Sodium acetate buffer $(100 \mathrm{mM}, \mathrm{pH} 7.5)$. The adsorbent sample was then eluted with $0.5 \mathrm{M}$ potassium 
chloride in same thebuffer. The protein-containing fraction was pooled and the enzyme solution was concentrated for further analysis. All the process was monitored at $280 \mathrm{~nm}$ absorbance.

\subsection{Determination of Total Protein}

The protein content was determined according to the method of (Bradford, 1976) using bovine serum albumin to obtain a standard curve. Each experiment was performed in triplicate.

\subsection{Determination of Fibrinolytic Activity}

Fibrinolytic activity was measured using the fibrin degradation assay. Firstly, $0.4 \mathrm{ml}$ of $0.72 \%$ fibrinogen was placed in a test tube with $0.1 \mathrm{~mL}$ of $245 \mathrm{mM}$ phosphate buffer $(\mathrm{pH} 7.0)$ and incubated at $37^{\circ} \mathrm{C}$ for $5 \mathrm{~min}$. Then, $0.1 \mathrm{~mL}$ of a $20-\mathrm{U} \mathrm{mL} \mathrm{m}^{-1}$ thrombin was added. The solution was incubated at $37^{\circ} \mathrm{C}$ for $10 \mathrm{~min}, 0.1 \mathrm{~mL}$ of diluted enzyme solution was added, and incubation continued at $37^{\circ} \mathrm{C}$. This preparation was mixed after $20-40 \mathrm{~min}$. At $60 \mathrm{~min}, 0.7 \mathrm{~mL}$ of $0.2 \mathrm{M}$ trichloroacetic acid was added and mixed. The reaction mixture was centrifuged at $15,000 \times \mathrm{g}$ for $10 \mathrm{~min}$. After that, $1 \mathrm{~mL}$ of the supernatant was collected and the absorbance at $275 \mathrm{~nm}$ was measured. Each experiment was performed in triplicate and the average value was then calculated after correction of the corresponding blank. In this assay, $1 \mathrm{U}$ (fibrin degradation unit) of enzyme activity was defined as a $0.01 / \mathrm{min}$ increase in absorbance at 275 $\mathrm{nm}$ of the reaction solution (Wanget al, 2011).

\subsection{Proteolytic activity}

Amidolytic activity was measured spectrophotometrically using the synthetic substrates: (S7388 Sigma) N-Succinyl-Ala-Ala-Pro-Phe p-nitroanilide -Chymotrypsin substrate, (G8148 Sigma) Gly-Arg-p-nitroanilide dihydrochloride - Urokinase and plasmin substrate. The mixture $(0.8 \mathrm{~mL})$ contained $30 \mu \mathrm{L}$ of enzyme solution, $30 \mu \mathrm{L}$ chromogenic substrate, and 140 $\mu \mathrm{L}$ of $20 \mathrm{mM}$ TRIS- $\mathrm{HCl}$ ( $\mathrm{pH} 7.4$ ). After incubation for $15 \mathrm{~min}$ at $37^{\circ} \mathrm{C}$, the amount of liberated p-nitroaniline (pNA) was calculated by spectrophotometric absorption at $405 \mathrm{~nm}$. One unit of amidolytic activity (AU) was expressed as micromoles of substrate hydrolyzed per minute and per milliliter by the enzyme. Each value is the mean of three determinations (Kim et al., 1996).

\subsection{Determination of molecular mass and isoelectric point (IEF)}

Sodium dodecyl sulfate polyacrylamide gel electrophoresis (SDS-PAGE) was carried out using a $12,5 \%$ polyacrylamide running gel according to (Laemmli, 1970). The molecular mass was approximately calculated using a molecular mass marker (Low-Range Rainbow Molecular Weight Markers - GE Healthcare) as a standard. Protein bands were detected by staining with Coomassie brilliant blue R-250.

The isoelectric focusing point $(\mathrm{pI})$ of enzyme was determined by two-dimensional electrophoresis (2-DE) according to the manufacturer's procedure. Isoelectric focusing (IEF) was carried out using 13-cm Immobiline DryStrip gels containing a preformed $\mathrm{pH}$ gradient immobilized in homogeneous polyacrylamide gels with a pH range of 3-10 (GE Healthcare).

The purified enzyme was loaded by in-gel rehydration with a reselling solution 
containing $8 \mathrm{M}$ of urea, $0.3 \%$ DTT (w/v) and 0.2\% (v/v) pH 3-10 IPG buffer. IEF was carried out at $20^{\circ} \mathrm{C}$ in a Multiphor II Electrophoresis System (GE Healthcare), wherein the voltage was linearly increased from 300 to $3500 \mathrm{~V}$ at $4 \mathrm{~V} / \mathrm{min}$ and kept constant for a further $3 \mathrm{~h}$. After IEF, the strip was equilibrated for $15 \mathrm{~min}$ in buffer containing $8 \mathrm{M}$ urea, 20\% glycerol, $2 \%$ SDS, $2 \%$ DTT and then for 15 min in the same buffer containing 2.5\% iodoacetamide instead of DTT. After equilibration, the strip was loaded on a 12.5\% SDS-PAGE gel for second-dimensional separation. The gel was then stained with Coomassie Brilliant Blue R250.

\subsection{Effect of inhibitors in protease activity}

To evaluate the effect of inhibitors, the purified sample was exposed to the following inhibitors, the concentration of the solutions was standardized at $5 \mathrm{mM}$,: PMSF (fluoride methylphenylsulfonyl- $\left.\mathrm{C}_{7} \mathrm{H}_{7} \mathrm{FO}_{2} \mathrm{~S}\right)$, mercuric chloride $\left(\mathrm{HgCl}_{2}\right)$, 2-mercaptoethanol (2-hydroxy-1-ethanethiol- $\mathrm{C}_{2} \mathrm{H}_{6} \mathrm{SO}$ ) and EDTA (Ethylenediaminetetraacetic acid - acetic $\mathrm{C}_{10} \mathrm{H}_{16} \mathrm{~N}_{2} \mathrm{O}_{8}$ ) and incubated for $60 \mathrm{~min}$ at $37^{\circ} \mathrm{C}$. The inhibitors were dissolved in $0,1 \mathrm{M}$ Tris- $\mathrm{HCl}, \mathrm{pH} 7.75$, with $0.15 \mathrm{M} \mathrm{NaCl}$.

\section{RESULTS AND DISCUSSION}

\subsection{Purification, determination of molecular mass and isoelectric point (IEF)}

The fibrinolytic enzyme was purified using the steps described in table 1, including acetone precipitation and ion exchange chromatography with DEAE-Sephadex column. The specific activity of the enzyme after purification, in comparison with the crude extract, was increased 10-times, with a recovery of $1.71 \%$. The yield of the purified enzyme after DEAE-Sephadex ionic exchange chromatography was about $3.63 \%$ of the relative fibrinolytic activity of the culture supernatant and the enzyme had a specific activity of $47.28 \mathrm{U} / \mathrm{mg}$ of protein.

Many reports revealed the use of acetone at different volume concentrations: 5 volumes, 3 volumes, and 2.5 volumes, as a primary precipitation agent for the recovery of proteases. Precipitation was also reported by various workers with acetone at different concentrations: $80 \%(\mathrm{v} / \mathrm{v}), 66 \%(\mathrm{v} / \mathrm{v})$; or 44,66 , and $83 \%(\mathrm{v} / \mathrm{v})$, followed by centrifugation and/or drying. Precipitation of enzymes can also be achieved by the use of water-soluble, neutral polymers such as polyethylene glycol(Kumar and Takagi, 1999).

A single-step chromatographic procedure, anion-exchange chromatography, was performed for purification of the fibrinolytic enzyme. Due to the residues of the culture supernatant, it was directly subjected to the column after clarification pre-treatment. This was an advantage when the purification strategy used in this work was compared to the purification of proteolytic enzymes produced under solid state fermentation conditions, where a number of steps need to be applied to remove excess salt (Yeginet al, 2012). Anion-exchange chromatography was a particularly critical step to the success of fibrinolytic enzyme NJP purification (Wang et al, 2011) and fibrinolytic enzyme NJF purified from the second active fraction (Deng et al, 2010). The fibrinolytic enzyme purified from mycelium of Perenniporiafraxinea showed 14.2-fold with a yield of $0.8 \%$ (Kim et al, 2008). The purified 
protease with fibrinolytic activity appeared as a single protein band on SDS-PAGE, and had a molecular weight of $15 \mathrm{kDa}$ and isoeletric point of 3.9 (Figure 2). The purification of protease has been summarized in Table 1.

Table 1. Purification steps of protease with fibrinolytic activity from Mucorsubtilissimus UCP 1262

\begin{tabular}{|c|c|c|c|c|c|c|c|c|}
\hline Steps & $\mathrm{AF}(\mathrm{U} / \mathrm{mL}$ & $\mathrm{AF}(\mathrm{U})$ & $\mathrm{PT}(\mathrm{mg} / \mathrm{mL})$ & $\mathrm{V}(\mathrm{mL})$ & PT(mg) & $\mathrm{SA}(\mathrm{U} / \mathrm{mg})$ & Fold & Yield $(\%)$ \\
\hline Crude Extract & 5.35 & 1605 & 0.006 & 300 & 1.8 & 891.66 & 1.00 & 100 \\
\hline Cetonic precipitate & 5.41 & 162.51 & 0.0104 & 30 & 0.31 & 520.86 & 1.71 & 10.12 \\
\hline DEAE-Sephadex & 1.96 & 5.90 & 0.0416 & 3 & 0.12 & 47.28 & 11.02 & 3.63 \\
\hline
\end{tabular}

The fibrinolytic activity was eluted as two peaks as showed in Figure 1, the second peak with maximum fibrinolytic activity was collected, dialyzed and concentrated by lyophilization, and used as the purified enzyme preparation. The purified fibrinolytic protease was shown as a single band in SDS-PAGE showed in Figure 2A and one protein spot in 2-DE as showed in Figure $2 \mathrm{C}$ and the purity of the enzyme was thus confirmed.

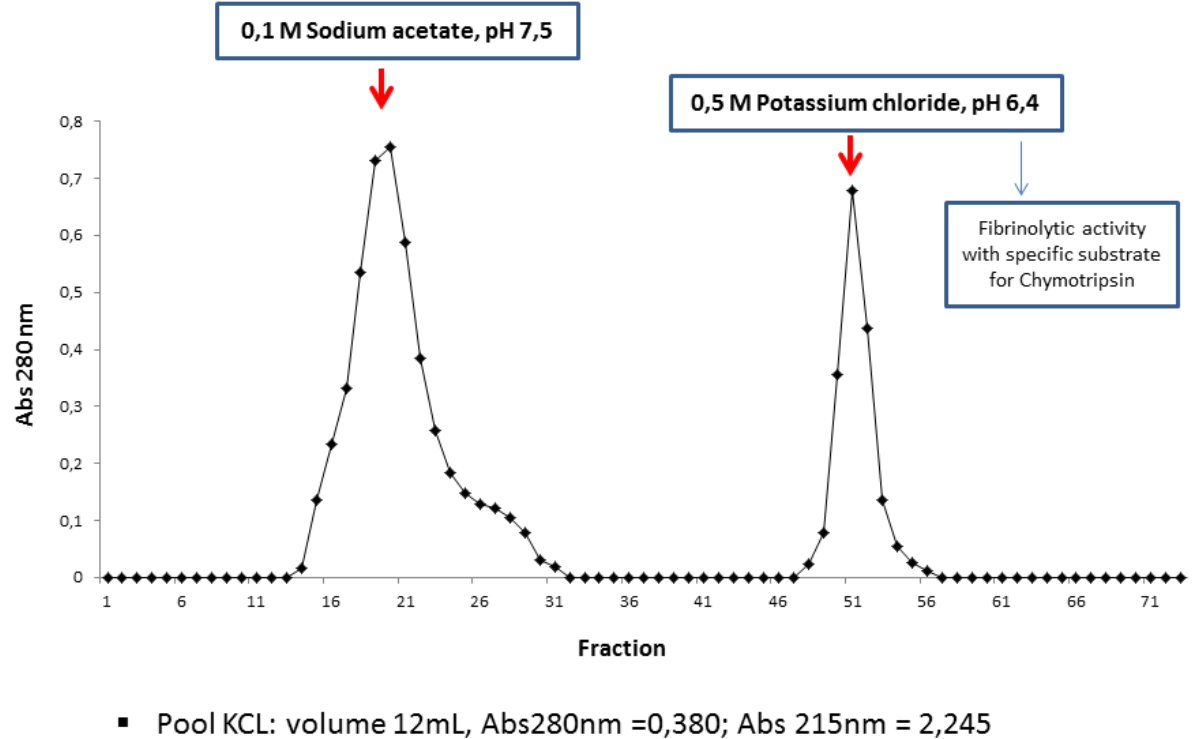

Figure 1 - Purification of fibrinolytic protease produced by Mucor subtilissimusUCP 1262. Anionexchange chromatography on a DEAE-Sephadex column $(8.0 \times 1.0 \mathrm{~cm})$ equilibrated with $0.1 \mathrm{M}$ Sodium acetate $(\mathrm{pH} 7.5)$, then eluted at a flow rate of $1.2 \mathrm{~mL} \mathrm{~min}^{-1}$ with linear gradient of $0.5 \mathrm{M}$ Potassium chloride (pH 6.4). 


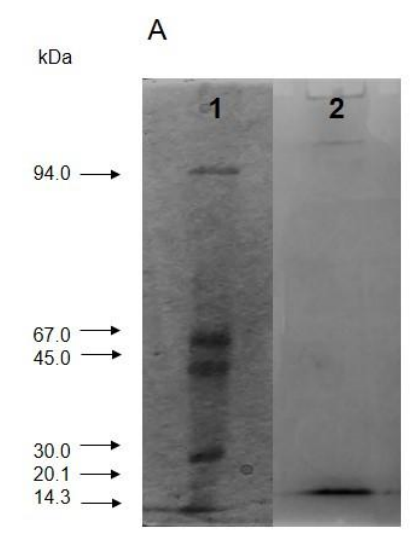

B
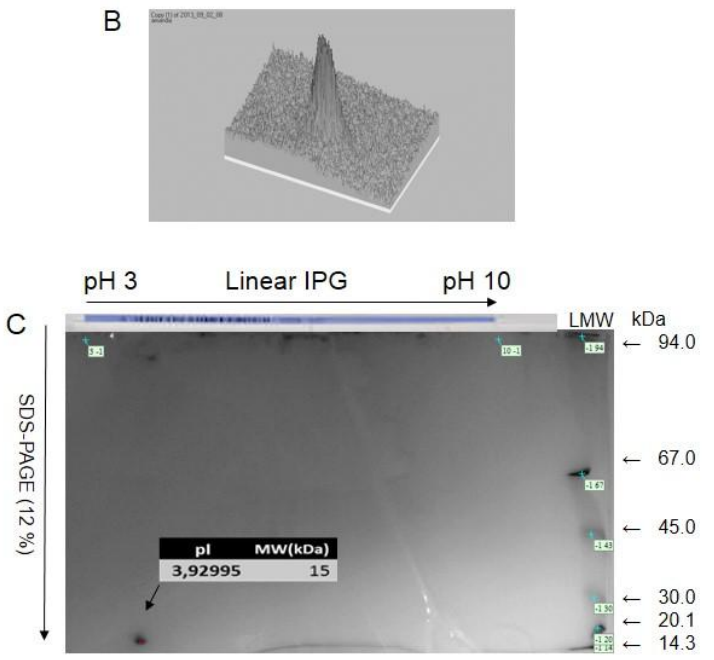

Figure 2 - SDS-PAGE (A), 3D-view of fibrinolytic protease obtained using Image Master software Platinum (GE Biosciences) (B) and 2-DE (C) of the purified fibrinolytic protease. (A) Lane 1, a standard LMW marker; Lane 2, purified fibrinolytic enzyme. (B) 3D-view of the purified fibrinolytic enzyme plot. (C) The first dimension was completed on immobilized $\mathrm{pH}$ 3-10 linear.

The purified fibrinolytic enzyme from Mucorsubtilissimus UCP 1262 with (15 kDa) is as small as the fibrinolytic enzyme purified from Paecilomycestenuipes (14 kDa). These enzymes have a molar mass lower than others fibrinolytic enzymes reported from fungi: Paecilomyces tenuipes(Kim et al, 2011), Fusarium sp. CPCC 480097(Wuet al, 2009), Armillaria mellea(Lee et al, 2005), Aspergillus oryzae KSK-3 (Shirasaka et al, 2012) andPerenniporia fraxinea (Kim et al, 2008).Comparative studies of thrombolytic enzymesfrom fungus with other emblematic thrombolytic agents revealed that these are low molar mass proteases, which may be an evidence for less immunogenicity character. Therefore, administration of these proteases in thrombolytic therapy, should not elicit the immune response against it. The therapeutic perspective of some of these agents is being evaluated in clinical trials (Arbind and Jagdeep, 2011).

The hydrolytic activity of the purified enzyme was measured using several chromogenic substrates. The highest level of fibrinolytic activity was observed with $\mathrm{N}$-Succinyl-Ala-Ala-Pro-Phe p-nitroanilide suggesting that it is a chymotrypsin-like protease. This type of fibrinolytic enzymes has also been reported from Armillariamellea(Lee et al, 2005), Perenniporiafraxineamycelia(Kim et al, 2008) andFomitellafraxinea(LEEet al, 2006). The purified sample with fibrinolytic activity was subjected to the protease inhibitors. The serinoprotease inhibitor, PMSF, showing a residual activity of $36.5 \%$, significantly inhibited enzyme activity. It has also been inhibited by iodoacetic acid $(54.5 \%)$ but was not inhibited in presence of pepstatin A, $\beta$ - mercaptoethanol and EDTA with residual activity of 93.9, 98.6 and $132 \%$ respectively. These results allowed characterizing fibrinolytic protease as a serinoprotease. Similar results were obtained by (Shirasaka et al, 2012), when the enzyme activity was considerably inhibited by serine protease inhibitors PMSF, but not by chelator agent EDTA. 


\section{CONCLUSIONS}

A chymotrypsin-like serineprotease with fibrinolyticactivity was purified from Mucorsubtilissumus UCP 1262. Its molecular weight was determined to be $15 \mathrm{kDa}$ which is one of the lowest among the so far reported from fungal enzymes. The purified fibrinolytic protease may represent a potential source of new therapeutic agents to treat thrombosis.

\section{ACKNOWLEDGEMENTS}

The authors are gratefull thanks to CAPES (National Council for the Improvement of Higher Education) for fellowshipand CNPq (National Council for Scientific and Technological Development), Brasilia, Brazil) for financial support.

\section{REFERENCES}

ANITHA, T. S., \& PALANIVELU, P. Purification and characterization of an extracellular keratinolytic protease from a new isolate of Aspergillus parasiticus. Prot. Express. Purif., v. 88(2), p. 214-20, 2013.

ARBIND, K., \& JAGDEEP, K. Fibrinolytic Agents in Reference to Fungi: An Overview. J. Pharm. Res., v. 4(11), p. 4225-4229, 2011.

BI, Q.; HAN, B.; LIU, W.; FENG, Y.; \& JIANG, Z. UFEIII, a fibrinolytic protease from the marine invertebrate, Urechis unicinctus. Biotechnol. Lett. V.35(7), p. 1115-20, 2013.

BRADFORD, M. M. A rapid and sensitive method for the quantitation of microgram quantities of protein utilizing the principle of protein-dye binding. Anal. Biochem., v. 72, p. 248-54, 1976.

CHOI, B. S.; SAPKOTA, K.; CHOI, J. H.; SHIN, C. H.; KIM, S.; \& KIM, S. J. Herinase: A Novel Bi-functional Fibrinolytic Protease from the Monkey Head Mushroom, Hericium erinaceum. Appl. Biochem. Biotechnol. v. 170(3), p. 609-22, 2013.

DENG, Z.; WANG, S.; LI, Q.; JI, X.; ZHANG, L.; \& HONG, M. Purification and characterization of a novel fibrinolytic enzyme from the polychaete, Neanthes japonica (Iznka). Biores. Technol., v. 101(6), p. 1954-60, 2010.

KIM, H. C.; CHOI, B. S.; SAPKOTA, K.; KIM, S.; LEE, H. J.; YOO, J. C.; \& KIM, S. J. Purification and characterization of a novel, highly potent fibrinolytic enzyme from Paecilomyces tenuipes. Process Biochem., v. 46(8), p. 1545-1553, 2011.

KIM, J. S.; KIM, J. E.; CHOI, B. S.; PARK, S. E.; SAPKOTA, K.; KIM, S.; KIM, S. J. Purification and characterization of fibrinolytic metalloprotease from Perenniporia fraxinea mycelia. Mycol. Res., v. 112 (8), p. 990-8, 2008.

KIM, W.; CHOI, K.; KIM, Y.; KIM, W.; CHOI, K.; KIM, Y.; LEE, S.. Purification and characterization of a fibrinolytic enzyme produced from Bacillus sp . strain CK 11-4 
screened from Chungkook-Jang Purification and Characterization of a Fibrinolytic Enzyme Produced from Bacillus sp . strain CK 11-4 Screened from Chungkoo k-Jang. V. 62(7), p. 2482-2488, 1996.

KUMAR BAJAJ, B., SHARMA, N., \& SINGH, S. Enhanced production of fibrinolytic protease from Bacillus cereus NS-2 using cotton cake as nitrogen source. Biocatal. Agricult. Biotechnol. v. 2(3), p. 204-209, 2013.

KUMAR, C. G., \& TAKAGI, H. Microbial alkaline proteases: from a bioindustrial viewpoint. Biotechnol. Adv., v. 17(7), p. 561-94, 1999.

LAEMMLI, U. K. Cleavage of structural proteins during assembly of head of bacteriophage T4. Nature, p. 680-685, 1970.

LEE, J. S.; BAIK, H. S.; \& PARK, S. S. Purification and characterization of two novel fibrinolytic proteases from mushroom, Fomitella fraxinea. J. Microbiol. Biotechnol., v. 16(2), p. 264-271, 2006.

LEE, S. Y.; KIM, J. S.; KIM, J. E.; SAPKOTA, K.; SHEN, M. H.; KIM, S.; KIM, S. J. Purification and characterization of fibrinolytic enzyme from cultured mycelia of Armillaria mellea. Protein Expr. Purif., v. 43(1), p. 10-7, 2005.

LU, C.; CHEN, S.; \& CHEN, S. Purification and Characterization of a Novel Fibrinolytic Protease from Schizophyllum commune, J. Food Drug Anal. v. 18(2), p. 69-76, 2010.

PORTO, A.L.F.; CAMPOS-TAKAKI; G. M. \& LIMA FILHO, J. L. Effects of culture conditions on protease production byStreptomyces clavuligerus growing on soy bean flour medium. Appl. Biochem.Biotechnol. v. 60, 1996.

SHIRASAKA, N.; NAITOU, M.; OKAMURA, K.; KUSUDA, M.; FUKUTA, Y.; \& TERASHITA, T. Purification and characterization of a fibrinolytic protease from Aspergillus oryzae KSK-3. Mycoscience, v. 53(5), p. 354-364, 2012.

WANG, S.; DENG, Z.; LI, Q.; GE, X.; BO, Q.; LIU, J.; HONG, M. A novel alkaline serine protease with fibrinolytic activity from the polychaete, Neanthes japonica. Comp. Biochem. Physiol. B. Biochem. Mol. Biol., v. 159(1), p. 18-25, 2011.

WANG, S.; WU, Y.; \& LIANG, T. Purification and biochemical characteri- zation of a nattokinase by conversion of shrimp shell with Bacillus subtilis TKU007. N. Biotechnol., v. 28(2), p. 196-202, 2011.

WU, B.; WU, L.; CHEN, D.; YANG, Z.; \& LUO, M. Purification and characterization of a novel fibrinolytic protease from Fusarium sp. CPCC 480097. J. Ind. Microbiol. Biotechnol., v. 36(3), p. 451-9, 2009.

YEGIN, S.; GOKSUNGUR, Y.; \& FERNANDEZ-LAHORE, M. Purification, structural characterization, and technological properties of an aspartyl proteinase from submerged cultures of Mucor mucedo DSM 809. Food Chemistry, v. 133(4), p. 1312-1319, 2012. 